\title{
Association between Neighborhood Parks and Leisure-time Physical Activity among Adult Mexican Women \\ Asociación entre parques de barrio y actividad física recreativa en mujeres mexicanas adultas

\author{
*Hilda García-Pérez, **Francisco Lara-Valencia \\ *El Colegio de la Frontera Norte (M éxico), **Arizona State U niversity (Estados Unidos)
}

\begin{abstract}
Although an extensive literature in developed countries suggests that elements of the urban built environment stimulate physical activity with beneficial health effects, information about this link in developing countries is still scarce. This study examines whether women's leisure-time physical activity (LTPA) is associated with neighborhood socioeconomic status, presence of public parks, and sociodemographic and health characteristics of women living in a mid-size M exican city. A multilevel logistic regression analysis was performed to test the association among a sample of adult women $(N=1,285)$ in Hermosillo, M exico. The analysis links two measures of LTPA to several metrics on park accessibility and neighborhood socioeconomic status. Twenty-two percent of women engaged in neighborhood-based physical activity (N PA), while 29\% engaged in overall physical activity (OPA). After adjusting by neighborhood socioeconomic status and individual-level variables, parks density, park-to-people ratio, combined parks' service areas, or distance to the nearest park were not related with NPA and OPA. Neighborhood socioeconomic status was the only contextual variable with a significant influence on women's NPA (AOR 1.05; 95\% CI 0.99-1.10) and OPA (AOR=1.06; 95\% Cl 1.01, 1.12). After controlling for neighborhood-level variables, women's age and education were al so statistically associated with physical activity. Based on the indicatorsused in this study, findings do not support a connection between the presence of parks and women's physical activity in Hermosillo's neighborhoods.
\end{abstract}

Keywords: Leisure-time physical activity, neighbourhood parks, women.

Resumen. Aunque numerosos estudios en países desarrollados sugieren que algunos elementos del ambiente urbano construido estimulan la actividad física, con efectos benéficos sobre la salud, el estudio de esta relación sigue siendo escasa en países en desarrollo. Este estudio examina la asociación entre la actividad física recreativa (AFR), y el estatus socioeconómico del barrio, la presencia de parques públicos, y las características sociodemográficas y de salud de mujeres residentes de una ciudad mexicana de tamaño medio. El análisis usa una regresión logística multinivel para probar esta relación en una muestra demujeres adultas $(n=1,285)$ en Hermosillo, M éxico. El análisis relaciona dosmedidas deAFR con indicadores de accesibilidad a parques y el estatus socioeconómico del barrio. Veintidós por ciento de las mujeres realizaron actividad física en su barrio (NPA), mientras que 29\% realizó actividad física general (OPA). Después de controlar el estatus socioeconómico del barrio y variables individuales, la densidad de parques, la razón parque-individuo, la suma de las áreas de servicio de los parques, y la distancia al parque más cercano, no estuvieron asociados con N PA y 0 PA. El estatus socioeconómico del barrio fue la única variable a nivel contextual asociada con NPA (AOR 1.05; 95\% CI 0.99-1.10) y OPA ( $\mathrm{AOR}=1.06 ; 95 \% \mathrm{Cl} 1.01,1.12$ ). Luego de controlar las variables de contexto, la edad y la educación de las mujeres estuvieron asociadas con laAFR. Conforme a los indicadores utilizados, los resultados no confirman una asociación entre la presencia de parques de barrio y AFR entre mujeres residentes de Hermosillo.

Palabras claves: Actividad física recreativa, parques de barrio, mujeres.

\section{Introduction}

The burgeoning body of research on the nexus between leisure-time physical activity (LTPA) and wellbeing has increased the attention to the significant disparities in access to active living environments encountered by multiple subpopulations and geographies

Fecha recepción: 23-09-20. Fecha de aceptación: 14-01-21

María Hilda GarcíaPérez

mhgarciaperez@colef.mx
(Salvo et al., 2017; Schipperijn et al., 2017). This perspective emphasizes the need to understand why some persons do not engage in sufficient physical activity and may not be getting all the physiological and psychological health benefits associated with an active lifestyle (Bermejo, Almagro, \& Rebollo, 2017; Blanco, Soto, Benitez, Mondaca, \& Jurado, 2019; Casper, Harrolle, \& Kelley, 2013). It also underscores the importance of approaches using a multilevel per spective amidst the growing evidence that engagement in 
physical activity is influenced by the interaction and intersection of individual, societal, and built environment factors (Carlson et al., 2012; Jáuregui et al., 2017; M itáš et al., 2019; Salvo et al., 2017; Schulz et al. , 2013; Talavera \& Saldaña, 2020)

As described by Henderson and Gibson (2013) in their integrative review, most women are likely to believe that LTPA is right for them, yet many are not able to be physically active on a regular basis. Research examining the role of gender on sport, fitness, exercise and other forms of free-time physical activity has consistently shown that women face more constraints than men on their access to leisure opportunities and resources (Blanco et al., 2019; Evenson, W illiamson, Han, McKenzie, \& Cohen, 2019). Although everyone is affected by the lack of facilities and limited opportunities due to daily life pressures, many women face a range of constraints resulting from perceptual and structural factors associated with their gender. Expectations and needs of the family, economic barriers, significant life changes, and safety concerns are among the major actors limiting the involvement of the female population in physical activity in general, but particularly of poor and minority women (Lara-Valencia \& García-Pérez, 2020; Ross \& Searle, 2019; W right Wendel, Zarger, \& Mihelcic, 2012).

Although mainstream research on leisure and women is shedding light on emerging and critical issues, including the role of leisure as a vehicle of resistance and empowerment, there is still a significant need for integrative studies on the complex interaction between individual (e.g., schooling) and contextual factors (e.g., features of neighborhoods) underpinning women's participation in LTPA (Day, 2006; M onforte \& Colomer, 2019). This need is particularly significant in the global south, where the field is in the early stages of development and systematic knowledge on motivation, patterns, barriers, and enabling factors of physical activity is very uncommon (Salvo, Reis, Sarmiento, \& Pratt, 2014). In the context of Latin America, in particular, women have been identified as a subpopulation experiencing low participation in sports and exercise activities, a major factor in the increasing risk of noncommunicable diseases and premature death, yet studies on LTPA participation and other aspects of the leisure experience are still limited (M itáš et al., 2019; W right Wendel et al., 2012).

In M exico, for instance, a 2019 study based on a representative sample reported that the week previous to the survey, $47.0 \%$ of M exican men aged 18 and over were engaged in sometype of LTPA (e.g., playing soccer, baseball, walking, etc.), while the percentage of active women was $37.7 \%$ (INEGI, 2020). Most Mexican reported exercising and practicing a sport in open and public spaces (INEGI, 2020; Salvo et al., 2017). Among women, LTPA increased with education, showing the highest prevalence in younger women (18 to 24 years). Another study showed that participation in LTPA is negatively correlated with work-related transportation time, and it is less prevalent among working women (Rodríguez Guajardo, Salazar Cantú, \& Cruz Ramos, 2013)

M exico'sfemale population is al so disproportionately affected by overweight and obesity. According to data from the 2018 M exican National Survey on Health and Nutrition (ENSANUT), $40.2 \%$ of M exican adult women are obese, while obesity affects only $30.5 \%$ of men (INSP, SS, \& INEGI, 2018). O besity especially targets poor women in urban areas, where the prevalence of obesity is approximately $17 \%$ higher than in rural communities (Shamah-Levy et al., 2019). The effect of overweight and obesity is significant, as $10.3 \%$ of M exican adult women have diabetes compared with $8.4 \%$ of adult men (Shamah-Levy et al., 2019). The findings of several studies agree that, aside from biological factors, obesity rates reflects the limited availability of affordable, healthy food in neighborhoods, along with urban conditions that discourage physical activity (Henderson \& Gibson, 2013; Johnson-Law rence, Schulz, Zenk, Israel, \& Rowe, 2015; Schulz et al., 2013). Thus, in addition to income and education, inadequate access to a healthy living environment are features of urban places, but especially of residential areas, that could be key to explain the prevalence of chronic diseases among Mexican women.

Studiesal so suggest that parks' density and proximity in residential areas improve residents' tendencies to engage in various forms of physical activity and healthier lifestyles (Elshahat, O 'R orke, \& Adlakha, 2020; Jáuregui, Salvo, M edina, Barquera, \& Hammond, 2020). In particular, the availability of parks and other green spaces in neighborhoods has been positively associated with the frequency of brisk walking (Nagel, Carlson, Bosworth, \& M ichael, 2008), spontaneous free play among residents (Ziviani et al., 2008), and recreational walking (Sugiyama et al., 2013). These studies propose that the distance to the nearest park is inversely correlated with the frequency of visitation, and that individuals living within walking distance from a park have a better chance to engage in leisure physical activity. 
Some of these studies, however, observe that although parks' availability and accessibility are enablers of LTPA, their influence varies across demographic groups, urban contexts, cultural practices, and physical activity domains (Elshahat et al., 2020; Evenson et al., 2019; Kaczynski et al., 2014; Schipperijn, Bentsen, Troelsen, Toftager, \& Stigsdotter, 2013; Stewart, Moudon, Littman, Seto, \& Saelens, 2018). The understanding of this variation is critical in the planning and implementation of actions to promote active lifestyles among local populations. To date, only a handful of studies have examined the influence of neighborhoods parks in the levels of people' physical activity in Latin America. The regional specificities of the culture, urbanization, and social dynamic of Latin American cities warrant research to understand the role of parks on LTPA.

In this study, we examine the association of the presence of neighborhood public parks, neighborhood socio-economic status, and women characteristics with their propensity to engage in LTPA. Understanding women's physical activity patterns and their correlates in urban neighborhoods of developing nations like Mexico is needed to expand the existing knowledge of the determinants of physical activity beyond female populations in NorthAmerica and Europe. As suggested by Stodolska (2000), although commonalities across populations are expected, the exploration of different experiences and their contextualization within the realities of the global south could contribute to the expansion of theory applicable to human leisure in general.

\section{M aterials and M ethods}

\section{Sampling and data collection}

The present analysis relies primarily on data from a survey conducted in 2005 among adult women living in the City of Hermosillo, Mexico. As the political and administrative center of the northern state of Sonora, provision of public services in Hermosillo is above average relative to M exican standards. Hermosillo had almost 642,000 residents in 2005 and only 2.3 percent of the housing units in the city lacked running water and 2.7 percent sewage connection (INEGI, 2005b). According to the Hermosillo' planning authority, the city was divided in about 358 residential neighborhoods and subdivisions called colonias (IMPLAN, 2014). The survey was part of a larger study examining several heal th outcomes that used a multistage systematic sampling procedure to obtain a neighborhood level sample of women aged 25-54 residents of Hermosillo (GarcíaPérez, Harlow, Erdmann, \& Denman, 2010). Firstly, a sample of 29 census enumeration districts was randomly selected from auniverse of 234 predominantly residential districts ( $\geq 50$ inhabitants) in Hermosillo. Secondly, ten urban blocks were randomly selected within each district and dwellings with each block were surveyed sequentially until approximately 45 eligible women were interviewed within each selected district. Thirdly, a short household screening questionnaire was applied to identify women aged 25-54 years old who were living in the house at the moment of the survey. In households with more than one eligible woman, one woman was randomly selected for the interview. A total of 1,420 eligible women were identified through this procedure, of whom 1,307 wereinterviewed (92\%), $49(3.4 \%)$ declined to participate, and 64 (4.5\%) could not be contacted. Respondents who did not answer the questions about LTPA were excluded from this analysis, as well as those individuals who lived in neighborhoods with less than five informants selected by the sampling procedure $(n=21)$. Thus, our final study population includes $n=1,285$ women in household and urban blocks dispersed in 44 «colonias» or neighborhoods. The interviews were conducted by nurses working for the state health department and trained by the principal investigator in the survey's methodology and the application of the survey's questionnaire. The study was approved by the Ethics Committee of the U niversity of Michigan, El Colegio de Sonora and El Colegio de la Frontera N orte. Participants were informed of the nature of the study and provided written informed consent.

\section{Leisure-time physical activity measures}

Leisure-time physical activity was measured using questions extracted from the sports/ exercise domain of the Kaiser Physical Activity Survey (Baecke, Burema, \& Frijters, 1982). The tool assesses LTPA using a 12month timeframe focusing on a large spectrum of women's health outcomes (Ainsworth, Sternfeld, Richardson, \& Jackson, 2000; Dugan, Bromberger, Segawa, Avery, \& Sternfeld, 2015; Lambiase\& Thurston, 2013). In addition of questions about morbidities such as urinary incontinence, pelvic pain and peri-menopause symptoms, women participating in the survey were asked the following question: During the past year, did you play a sport or exercise? Those participants responding affirmatively were asked to report the most common activity performed and respond to two 
questionsabout the activity duration (hours/ week) and its relative intensity (none, small, moderate, or large increase in heart rate and breathing).

These responses were used to construct two outcome variables at the individual level. The first variable is neighborhoodbased physical activity (NPA), which includes activities like walking, jogging, and running that are likely to be conducted in a variety of outdoor neighborhood settings such as parks, streets, pla

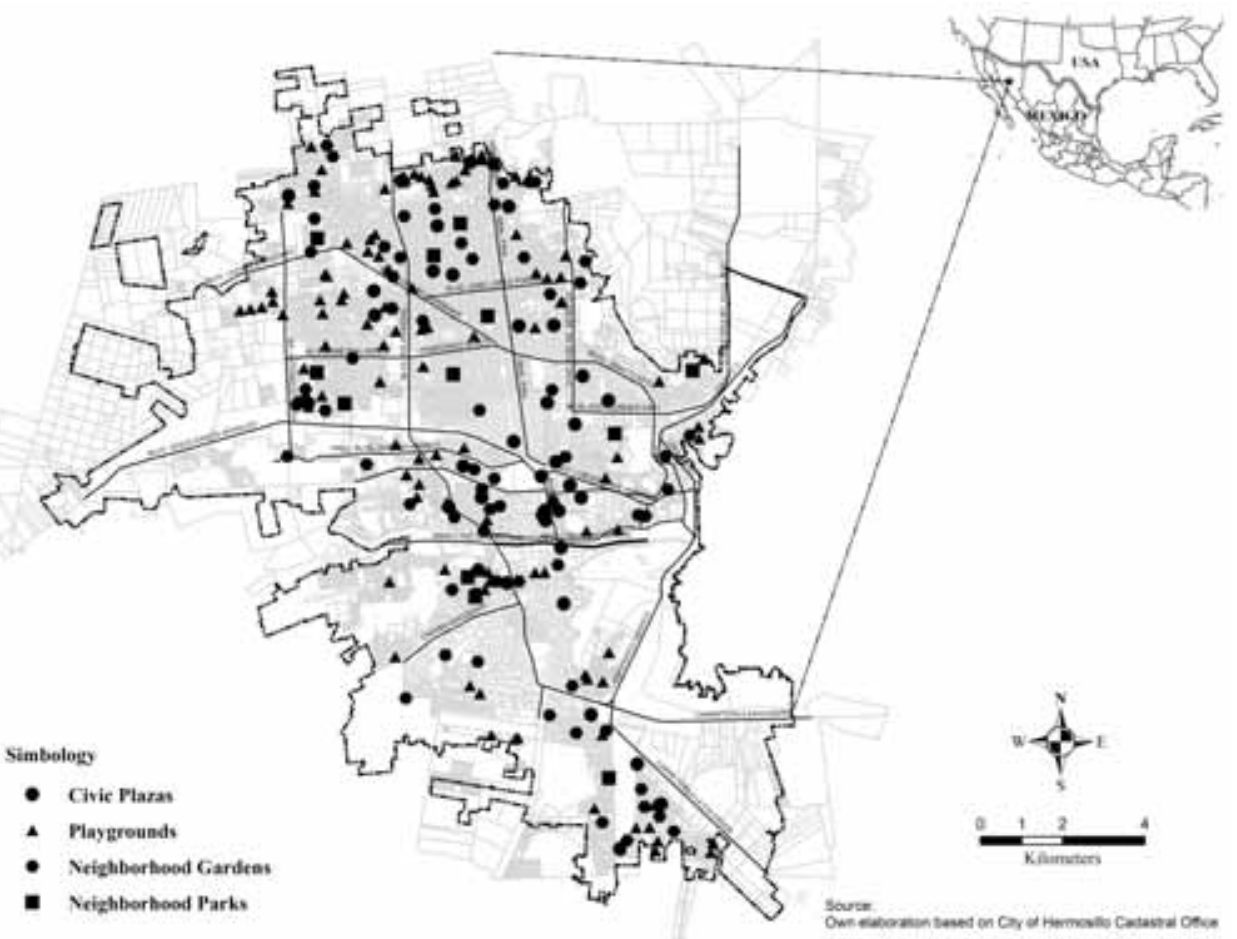
zas and other open spaces close to home. Women's responses were dichotomized as active if they walked or ran (yes $=0$ ) versus not active if they answered negatively or performed activities other than walking or running (no $=1$ ). O verall leisure-time physical activity (OPA) was also measured as a binary variable, where a woman was categorized as active (yes $=0$ ) if during the last 12 months she regularly practiced an organized sport, such asyoga, dancing, boxing, or cycling requiring more specialized settings plus running, jogging or walking; or as inactive (no $=1$ ) if she responded negatively. Because the inclusion of activities requiring more specialized settings, such as gyms, this measurement was expected to be less sensitive to the presence of parks in the neighborhood.

\section{Neighborhood Built Environmental and Socioeconomic Variables}

A database containing information on the geographic location, area, type, and other characteristics of green areas was created with information provided by Hermosillo's Cadastral 0 ffice and Parks Department (see figure 1). A total of 499 green areas, including parks, gardens, playgrounds, plazas, and street medians of all sizes, were inventoried and integrated into a geographical information system (GIS). Because this study focuses on public parksthat can be used for walking, jogging or running, green spaces with an area below $1,120 \mathrm{~m}^{2}$ were excluded from the analysis, a criterion suggested by Mexican guidelines and applied in similar studies conducted in other Latin America cities (Parra,

Gómez, Fleischer, \& Pinzón, 2010; SEDESO L, 1999). Also excluded was land designated as green areas such as street medians- but not equipped for passive or active recreation. Applying these criteria, 222 public parks within Hermosillo were identified and verified through in situ audits and remote analysis using Google Earth imagery. The majority of the facilities identified were classified as playgrounds ( $n=109,49.1 \%$ of the total), gardens $(n=67,30.2 \%)$, and plazas $(n=34,15.3 \%)$ and parks $(n=12,5.4 \%)$. In terms of size, most of the facilities tend to be near the lower limit of the recommended area by the M exican government within each category. Average size ranged from 1,770 $\mathrm{m}^{2}$ (playgrounds) to $17,400 \mathrm{~m}^{2}$ (neighborhood parks).

Four different objective measures of park availability and accessibility were derived using as point of reference the urban block were women in the survey had their place of residence. Availability was measured through a simple tally of the number of parks within each neighborhood but also by calculating the ratio of parks to people residing within each neighborhood. Accessibility is a distance-based metric. It was determined by calculating the Euclidian distance between the survey respondents' residential block and the centroid of the polygon representing the nearest park, regardless of its location within or outside the neighborhood. To test the potential influence of distance, three proximity classes were used: $<350 \mathrm{~m}, 350-750$ $\mathrm{m}$, and $>750 \mathrm{~m}$. The lower $(350 \mathrm{~m}$ ) and upper distances $(750 \mathrm{~m})$ of the three proximity classes corresponds to the service areas recommended by the Mexican 
government for the different type of neighborhood public parks (SEDESO L, 1999). Accessibility was also measured as the ratio resulting from dividing the aggregated area of the $750 \mathrm{~m}$ concentric radii around each park overlapping the neighborhood's territory, divided by the neighborhood's total land area. The formula used is:

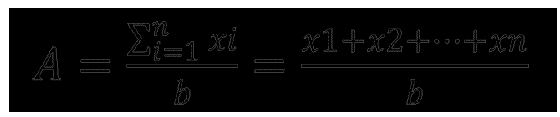

Where $A$ is the ratio of the sum of all the park concentric circles overlapping the neighborhood's extent, $\mathrm{x}$ is the park service area $\left(\mathrm{m}^{2}\right)$ overlapping the neighborhood, and bisthearea $\left(\mathrm{m}^{2}\right)$ of the neighborhood. The inclusion of these two last indicators compensates for the edge effect, a common problem of studies using the so-called container approach (Talen, 1997).

N eighborhoods' socio-economic statuswas measured using principal-component analysis to construct a socioeconomic status index (SESi). This index combines data from the 2005 Population Count on characteristics and services connected to dwellings as well as on household ownership of durable goods such as a television, computer, and refrigerator. This type of index provides a reasonable proxy of poverty/ affluence in countries where data on income or expenditure is not reliable or existent (Filmer \& Pritchett, 2001). In general, a high SESi score reflects a neighborhood with a higher proportion of people with relatively higher income and households with a relatively high number of assets. In contrast, alow SESi score indicates a neighborhood with a high proportion of people with lower income and householdswith fewer assets. Detailed information about the construction of the index has been published elsewhere (LaraValencia \& GarcíaPérez, 2015)

\section{Individual measures}

The analysis also includes a number of individuallevel covariates to control for the influence of anthropometric and socio-demographic factors, including age, education, marital status, occupational status, migratory status, parity, pregnancy status, body mass index and diabetes. Age was assessed as an interval va riable, while education was measured as a dichotomous variable (at least a year of high school as cut-point). 0 ther individual covariates were the number of children and women's occupational status the week before the survey (employed or seeking employment versus others). Bodyweight in kilograms was assessed with a digital scale by nurses at the end of the interview (Tanita
2001W-B U Itimate Body Fat Scale) with participants wearing light clothing and no shoes. Height was measured using a dressmaker's measuring tape and recorded to the nearest half centimeter. BMI was then calculated as weight-for-height $\left(\mathrm{kg} / \mathrm{m}^{2}\right)$. Diabetes was assessed using a combination of two measurements: the response to the question «H ave you ever been told by a doctor that you have diabetes», and/ or the outcome of a blood glucose test (García-Pérez, Harlow, \& Denman, 2018). For the test, we used the Accu-Chek Active System (Roche) to carry out a casual blood glucose test at the time of the interview. Any value greater than or equal to $200 \mathrm{mg} / \mathrm{dL}$ at any time of the day was considered abnormal (Rojas de P, Molina, \& Rodríguez, 2012). U sing a finger stick, 1- $\mu \mathrm{L}$ capillary blood samples were drawn into a test strip and this strip was then inserted into the Accu-Chek Active Blood Glucose M eter. In this study, $5.9 \%$ of participants had been diagnosed with dia betes, whereas $1.0 \%$ had an abnormal casual blood glucose test. Participants were provided with a copy of the glucose test and were alerted if their results were abnormal.

\section{Analysis}

We used SAS GLIMIX (SAS ver sion 9.3) to compute a two-level multiple logistic regression. The influence of neighborhood-level variables on LTPA while controlling for individual-level variables was assessed. Random-effect log-linear models with a random intercept for each neighborhood were used to obtain odds ratios of the association between LTPA and parks' availability and accessibility (Raudenbush \& Bryk, 2002; Sundquist \& Yang, 2007). U sing this approach, a set of three models was examined. The first model examines the relationship of parks' availability and accessibility measures on the estimates of the two outcomes of physical activity (NPA and OPA) across neighborhoods. A second model examines the association of parks' availability and accessibility covariates plus the influence of neighborhood socio-economic status on NPA and OPA. These two models allowed the exploration of the influence of neighborhood's built environment and social characteristics separately. Finally, all the individuallevel and neighborhood-level variables were combined into a single model. In the final analysis, we decided to drop marital status, occupation, number of children, pregnancy, BMI and diabetes, because some of these individual variables were highly correlated and did not show an association with women's leisure-time physical activity. The models' coefficients provide estimates of 
the relationships of the individual- and neighborhoodlevel variables to the study's measures of LTPA. As explained above, both NPA and OPA are assessed as dichotomous outcomes. Since the reference outcome was women's not engaging in physical activity, the coefficients estimated through these models indicate women's likelihood of being physically active. 0 dds ratios and $95 \%$ confidence intervals are reported for all the effect estimates.

\section{Results}

Table 1 shows the descriptive statistics of individuallevel and neighborhood-level variables used in the analysis. In total, $21.9 \%$ of participants engaged in neighborhood-based physical activity (NPA) during the 12 months prior to the survey, while $28.9 \%$ were physically active in general (O PA). Women in the sample averaged 38.5 years of age, while the number of years they had been living in Hermosillo was almost 31 years, a period suggesting long-term exposure to and familiarity with the city. Almost $60 \%$ of the respondents stayed at home, and the rest were employed or seeking employment.

\begin{tabular}{|c|c|c|c|c|}
\hline & $\mathrm{n}(\%)$ & Mean & Std. Dev. & Range \\
\hline \multicolumn{5}{|l|}{ Individual-level outcomes $(\mathrm{n}=1285)$} \\
\hline Neighborhood based leisure-time physical activity (NPA) & $282(21.9)$ & & & \\
\hline O verall leisure-time physical activity (O PA) & $372(28.9)$ & & & \\
\hline \multicolumn{5}{|l|}{ Individual-level Covariates } \\
\hline \multicolumn{5}{|l|}{ Age groups } \\
\hline 25-34 years & $475(37.0)$ & & & \\
\hline $35-44$ years & $456(35.5)$ & & & \\
\hline 45-54 years & $354(27.5)$ & & & \\
\hline \multicolumn{5}{|l|}{ Education } \\
\hline$<$ High school & $867(67.5)$ & & & \\
\hline 2High school & $417(32.5)$ & & & \\
\hline Missing & 1 & & & \\
\hline \multicolumn{5}{|l|}{ Marital status } \\
\hline Married/ Living as married & $1016(79.1)$ & & & \\
\hline Other & $269(20.9)$ & & & \\
\hline \multicolumn{5}{|l|}{ Occupation } \\
\hline Employed/Self-employed/ looking for a job & $506(39.4)$ & & & \\
\hline Other & $779(60.6)$ & & & \\
\hline Pregnant during the last 12 months $(n=1,283)$ & 8.0 & & & \\
\hline Number of children $(n=1,284)$ & & 2.8 & 1.6 & $0-13$ \\
\hline Body mass index $\left(\mathrm{kg} / \mathrm{m}^{2}\right)(\mathrm{n}=1,268)$ & & 29.4 & 5.9 & $15.7-57.7$ \\
\hline Diabetes & $89(6.9)$ & & & \\
\hline Native of Hermosillo & $755(58.8)$ & & & \\
\hline Missing & 1 & & & \\
\hline \multicolumn{5}{|l|}{ Neighborhood-level covariates $(n=44)$} \\
\hline Socioeconomic status index (SESi) & & 0.4 & 3.6 & $-13.5-6.1$ \\
\hline Number of parks in the neighborhood & & 0.8 & 1.6 & $0-7$ \\
\hline Park-to-people ratio (m² of park per resident) & & 0.3 & 1.1 & $0-13.4$ \\
\hline Distance to nearest park from residence (meters) & & 477.5 & 284.8 & $55.1-1219.5$ \\
\hline Number of overlapping $750 \mathrm{~m}$ park's service areas & & 7.1 & 6.4 & $0-24$ \\
\hline
\end{tabular}

A bout a third of women completed at least one year of high school and $79.1 \%$ declared being married/ living as married and having an average of 2.8 children. About $8 \%$ of the respondents were pregnant during the 12 months before the survey. The respondents' average BMI was $29.4 \mathrm{~kg} / \mathrm{m}^{2}$, a level indicative of overweight and borderline obesity. According to the definition used in this analysis, $6.8 \%$ of the participants had diabetes.

Extensive variation in socio-economic status and park availability and accessibility were observed across neighborhoods. The average SESi was 0.44 (SD 3.61), with neighborhoods above the mean distributed almost randomly across the city. The average number of parks was 0.78 units (SD 1.57). O nly $32 \%$ of the colonias had at least one park of minimally $1,200 \mathrm{~m}^{2}$ in area. The park area per resident was estimated to be $0.34 \mathrm{~m}^{2}$ per resident, which is considerably below the city target of $1.1 \mathrm{~m}^{2}$ per inhabitant and the internationally accepted minimum of $9 \mathrm{~m}^{2}$ per inhabitant (IMPLAN, 2014; Pafi, Siragusa, Ferri, \& Halkia, 2016; SEDESO L, 2010).

Regarding accessibility to parks, the average distance to the near est park was approximately $478 \mathrm{~m}$ (SD 285m) and the minimum distance was $56 \mathrm{~m}$. Proximal overlapping service areas averaged 7.1 units. It is important to note that accessibility and availability to parks tend to be higher in neighborhoods located at the city's core than in the periphery and that poor neighborhoods are less likely to have access to public parks.

Table 2 shows characteristics of LTPA, women's selfreported heart rate and breathing variations while exercising, and frequency of LTPA participation (h/ week). Walking was the most reported activity $(71.7 \%)$, followed by aerobics or Pilates $(10.6 \%)$ and biking (7.5\%). 0 ther activities reported less frequently were team sports participation (basketball, volleyball, racquetball, or soccer), running, dancing, swimming, kickboxing, etc. The choice of activity is correlated with the intensity of the physical exertion, as indicated by the fact that almost $80 \%$ of the women reported noneto-small variation in heartbeat or breathing during the activity. Regarding frequency, only a third of the women exercised two or more hours per week.

\begin{tabular}{lc}
\begin{tabular}{l} 
Table 2. \\
Type of activity, changes in heartbeat and frequency of LTPA ( $\mathrm{n}=372)$ \\
\hline Leisure-time physical activities*
\end{tabular} \\
\hline Walking & $\mathrm{n}(\%)$ \\
Aerobics or Pilates & $417(71.7)$ \\
Cycling & $29(7.5)$ \\
Basketball, volleyball, racquetball, or soccer & $8(2.0)$ \\
Running/ jogging & $7(1.8)$ \\
Dancing & $5(1.3)$ \\
Swimming & $4(1.0)$ \\
Abdominals & $4(1.0)$ \\
Yoga/ tai-chi & $3(0.7)$ \\
Kickboxing & $3(0.7)$ \\
Weights or stationary bike & $3(0.7)$ \\
Gymnastic & $2(0.5)$ \\
\hline Relative increase in heartbeat and breathing & \\
\hline None-to-Small & $291(79.7)$ \\
Moderate-to-vigorous & $74(20.3)$ \\
Missing & 7 \\
\hline Duration (hours per week) & $125(34.4)$ \\
\hline Less than 1 hour & $118(32.5)$ \\
$1<2$ hours & $120(33.1)$ \\
$\geq 2$ hours & 9 \\
\hline Missing &
\end{tabular}


Table 3 presents coefficient estimates resulting from the multilevel analysis for NPA. 0 ur results indicate no evidence that the number of parks, park-to-people ratio, frequency of combined service areas, or distance to the nearest park have any influence on physical activity among women aged 25 to 54 years old in Hermosillo (model 1). 0 nly after adjusting by neighborhood socioeconomic status, distance to the nearest park Model 2 showed some effect on NPA $(p<0.07)$, but the regression indicated a similar non-significant association. Under this model, women residing between 350 to 750 meters from a park had an increase of $48 \%$ in the odds of walking and running relative to women living at more distant locations $(95 \% \mathrm{Cl} 0.96,2.30)$. O n the other hand, SESi increased the odds of women's engagement in N PA by $8 \%(95 \% \mathrm{Cl} 1.02,1.13)$ after controlling for parkrelated variables.

\begin{tabular}{|c|c|c|c|}
\hline & Model $1^{\mathrm{a}}$ & Model $2^{b}$ & Model $3^{c}$ \\
\hline \multicolumn{4}{|l|}{ Fixed Parameter } \\
\hline Constant & -1.3797 & -1.5271 & -1.7318 \\
\hline \multicolumn{4}{|l|}{ Park provision predictors } \\
\hline Number of parks & $1.00(0.85,1.17)$ & $0.99(0.87,1.14)$ & $1.00(0.88,1.14)$ \\
\hline Combined service areas & $0.99(0.95,1.02)$ & $1.00(0.96,1.03)$ & $1.00(0.97,1.03)$ \\
\hline Park area per resident & $0.92(0.84,1.02)$ & $0.92(0.84,1.01)$ & $0.93(0.84,1.01)$ \\
\hline \multicolumn{4}{|l|}{ Distance to nearest park } \\
\hline$<350 \mathrm{~m}$ & $1.28(0.75,2.20)$ & $1.32(0.80,2.17)$ & $1.35(0.83,2.19)$ \\
\hline $350-750 \mathrm{~m}$ & $1.39(0.88,2.21)$ & $1.48(0.96,2.30)$ & $1.49(0.97,2.29)$ \\
\hline$>750 \mathrm{~m}$ & 1.0 Reference & 1.0 Reference & 1.0 Reference \\
\hline \multicolumn{4}{|l|}{ Neighborhood SES } \\
\hline SESi & na & $1.08(1.02,1.13)$ & $1.05(0.99,1.10)$ \\
\hline \multicolumn{4}{|l|}{ Individual-level predictors } \\
\hline \multicolumn{4}{|l|}{ Age group } \\
\hline $25-34$ years & \multirow{3}{*}{ na } & \multirow{3}{*}{ na } & $0.68(0.48,0.97)$ \\
\hline $35-44$ years & & & 1.0 Reference \\
\hline $45-54$ years & & & $1.47(1.04,2.08)$ \\
\hline $\begin{array}{l}<\text { High school } \\
\geq \text { High school }\end{array}$ & na & na & $\begin{array}{c}\text { 1.0 Reference } \\
1.76(1.29,2.40)\end{array}$ \\
\hline \multicolumn{4}{|c|}{ Random parameters } \\
\hline Between-neighborhoods variation & $0.15(0.09)^{d}$ & $0.77(0.07)$ & $0.050(0.06)$ \\
\hline \multicolumn{4}{|c|}{$\begin{array}{l}\text { 'A Adjusted for built environment and neighborhood deprivation variables } \\
\text { cAdjusted for built environment, neighborhood deprivation, age and educational attainment } \\
\text { d Statistically significant at } 0.05 \text { level }\end{array}$} \\
\hline \multicolumn{4}{|l|}{ Table 4.} \\
\hline \multicolumn{4}{|c|}{ Two-level odds ratios for overall LTPA } \\
\hline & Model $1^{\mathrm{a}}$ & Model $2^{b}$ & Model 3c \\
\hline \multicolumn{4}{|l|}{ Fixed Parameter } \\
\hline Constant & -0.9405 & -1.0945 & -1.4445 \\
\hline \multicolumn{3}{|l|}{ Park provision predictors } & $1.01(0.87,1.18)$ \\
\hline Combined service area & $0.98(0.94,1.02)$ & $0.99(0.95,1.03)$ & $0.99(0.96,1.03)$ \\
\hline Park area per resident & $0.94(0.85,1.03)$ & $0.94(0.86,1.02)$ & $0.94(0.86,1.02)$ \\
\hline \multicolumn{4}{|l|}{ Distance to nearest park } \\
\hline$<350 \mathrm{~m}$ & $1.20(0.68,2.11)$ & $1.23(0.72,2.09)$ & $1.22(0.73,2.05)$ \\
\hline $350-750 \mathrm{~m}$ & $1.29(0.81,2.07)$ & $1.35(0.86,2.12)$ & $1.36(0.87,2.11)$ \\
\hline$>750 \mathrm{~m}$ & 1.0 Reference & 1.0 Reference & 1.0 Reference \\
\hline \multicolumn{4}{|l|}{ Neighborhood SES } \\
\hline SESi & na & $1.09(1.03,1.15)$ & $1.06(1.01,1.12)$ \\
\hline \multicolumn{4}{|l|}{ Individual-level predictors } \\
\hline \multicolumn{4}{|l|}{ Age group } \\
\hline $25-34$ years & \multirow{3}{*}{ na } & \multirow{3}{*}{ na } & $0.84(0.611 .14)$ \\
\hline $35-44$ years & & & 1.0 reference \\
\hline 45-54 years & & & $1.44(1.02,2.04)$ \\
\hline$<$ High school & na & na & 1.0 Reference \\
\hline$\geq$ High school & & & $1.68(1.26,2.24)$ \\
\hline \multicolumn{4}{|l|}{ Random parameters } \\
\hline Between-neighborhood variation & $0.31(0.12)^{d}$ & $0.21(0.10)^{d}$ & $0.17(0.93)^{d}$ \\
\hline
\end{tabular}

As can be observed in model 3 , a positive association was found between SESi and NPA, but the regression showed a non-significant association ( $A O R=1.05 ; 0.99$ 1.10), after adjusting by individual-level (age and education) and park-related variables. At the individual level, age and education were associated with N PA; thus, older women were significantly more likely than younger women to have walked or jogged, and more educated women were more likely to engage in this activity than less educated (model 3).

Table 4 estimates the influence of neighborhood and individual-level variables on O PA. Similar patterns in the association between neighborhood-level variables in O PA were observed. M odel 3 seems consistent with the SESi in increasing the odds of women's engagement in $0 \mathrm{PA}$ by $6 \%(95 \% \mathrm{Cl} 1.01,1.12)$ after controlling by park-related variables and women's age and education. All the relationships between OPA and individual covariates were in the expected direction and were statistically significant.

\section{Discussion}

This study investigated the influence of objectively measured dimensions of park provision, neighborhood socio-economic status and individual characteristics related to LTPA in a large representative sample of women aged 25 to 54 years, living in Hermosillo. Detected physical activity levels were consistent with other studies reporting that participation of M exican women in LTPA is generally low (INEGI, 2005a, 2020; Mitáš et al., 2019; Rodríguez Guajardo et al., 2013). Prevalence rates were estimated at $21.9 \%$ for NPA and $28.9 \%$ for OPA. Walking was the most important type of NPA (71\%) undertaken by women in Hermosillo, followed distantly by running and cycling. These results are consistent with the findings of other studies in Latin America (Guimarães et al., 2019; Salvo et al., 2017). These activities are performed at a very low pace and for a short time, so most women did not report a significant change in heartbeat and breathing as a result of the exertion (79.7\%), and only one third exercised more than two hours per week. This is clearly below the recommended international guideline of at least 150-300 minutes of moderate-intensity aerobic physical activity; or at least 75-150 minutes of vigorousintensity aerobic physical activity; or an equivalent combination of moderate- and vigorous-intensity activity throughout the week, for substantial health benefits» (W HO, 2020).

Women aged 25 to 34 years were less likely to engage in LTPA, an outcome also observed in other 
studies (Hernandez et al., 2003; INEGI, 2020). It is possible that the lower prevalence of LTPA among younger adult women is partially due to greater familial responsibilities and work, while older women might be more inclined to exercise due to health concerns and lower family obligations. In fact, an exploratory study among adult women in Hermosillo found that older women are more likely to use the neighborhood's streets to walk, attend a Zumba class at the neighborhood park, and experience more freedom to engage in leisurely activities than younger women (García-Pérez \& Lara-Valencia, 2016). In contrast, as reported elsewhere, younger women are more likely to describe themselves as individuals with limited leisure time due to work and/ or family responsibilities (INEGI, 2020; Valenzuela \& M eléndez, 2019). Having high school or higher education was independently associated with an increase in both women's NPA and OPA. Similar findings have been reported elsewhere (INEGI, 2020; M itáś et al., 2019; Ross \& Searle, 2019).

We assumed that higher availability and accessibility of neighborhood parks would be positively associated with LTPA, and in particular, would stimulate neighborhood-based activities such as walking and running. Contrary to our hypothesis, we found that parks' presence and proximity seemed to contribute little to the level of women's LTPA. O ur findings did not show that higher provision of parks was correlated with LTPA under any of the physical activity metrics scrutinized. O ne dimension showing some effect was the distance to the nearest park, but regression analysis revealed a non-significant association for both N PA and O PA. 0 ther studies elsewhere had also reported no association between parks and LTPA in females. Recent analyses concluded that, although distance to parks is generally associated with increased activity, this link is more dependent on the type of parks (Bojorquez, O jedaRevah, \& Diaz, 2018; Jáuregui et al., 2017; Salvo et al., 2017; Soltero, Scherezade, Pacheco, \& Lee, 2015). 0 ther built environment factors associated with park accessibility such as street connectivity, sidewalks, street lighting and perceived neighborhood safety and walkability may also influence women's NPA, as suggested by some studies (García-Pérez \& Lara-Valencia, 2016; Joseph \& Maddock, 2016). In Hermosillo's case, this lack of association could also be attributed to parks' limited attractiveness. Although Mexican standards prescribe the planting of trees and other vegetation in parks, it is common that green areas in Mexican cities are not well maintained, giving the appearance of abandonment and disarray (0 jeda-Revah, Bojorquez, \& 0 suna, 2017). O ther studies have also shown that people are more likely to visit and exercise in parks if they have the proper layout, and in general, are attractive (GarcíaPérez \& Lara-Valencia, 2016; A. Jáuregui et al., 2017; Soltero et al., 2015). Due to lack of data, perceptions of park attractiveness, as well as the sense of neighborhood safety, were not explored in this analysis.

Besides, the neglect of gender-specific needs and values can also inhibit women's utilization of parks. In Hermosillo, parks' layouts and amenities favor maleoriented activities over those preferred by women. For example, some public spaces include soccer or baseball fields and rarely include formal pathways for walking and jogging, two of the most common activities reported by women participating in the survey. Many women in the sample were mothers with caregiving responsibilities, so it is plausible to assumethat for some, it can be challenging to use parks with no access ramps for strollers or without spaces where they can exercise while supervising children. Therefore, it is likely that improperly equipped parks, unkempt or with no vegetation, could be another factor explaining women's inactivity.

The neighborhood SESi was significantly associated with being physically active. 0 ther studies that have included neighborhood-level income measures in their analysis have al so reported positive associations between higher levels of deprivation and higher rates of inactivity among women (Diez-Roux, Link, \& N orthridge, 2000; Nakamura, Teixeira, Hino, Kerr, \& Kokubun, 2016). This is possibly the result of the clustering of households with similar income levels and its impact on the neighborhood's material and social characteristics. In Hermosillo, high SESi neighborhoods are often master-planned communities, in which provision of paved streets, sidewalks and lighting is standard. In contrast, Iow SESi neighborhoods are usually unplanned residential areas that frequently lack necessary urban infrastructure. Some of the high SESi neighborhoodswerealso designed as gated communities, where safety is marketed as the top amenity. Studies conducted in other contexts have reported that street safety, crime levels, and perceived insecurity also influence women's utilization of parks (Jáuregui et al., 2016). In fact, most H ermosillo residents characterize their city and street neighborhoods as insecure, with women having a more negative perception of security than men (GarcíaPérez $\&$ Lara Valencia, 2016; INEGI, 2016). Indeed, urban violence 
and crime have reached epidemic levels in Mexico in the last decade, especially in the northern region, where Hermosillo is a major urban center (INEGI, 2019).

\section{Limitations}

This study has several limitations and strengths. As a cross-sectional analysis, this study is unable to identify any causal link between neighborhood features and LTPA. Also, the study relies on self-reported activity accounts during the past 12 months, a procedure that is subject to recall bias. Further, park features and women's perception of parks as safe or hazardous places were not examined. Studies concentrating on the qualitative dimensions of park usage and neighborhood's perceived safety should be prioritized in future research. Despite these limitations, our study is one of the few in Mexico using a multilevel approach to directly assess the social and built environmental correlates of LTPA based on a sizeable probabilistic survey and GIS data at the neighborhood level. It also contributes knowledge and creates opportunities for the expansion of leisure and women studies by extending research customarily conducted in developed nations to a city in a developing nation where studies of thiskind are scarce and therefore urgently needed (A. Jáuregui et al., 2017; Salvo et al., 2014).

\section{Conclusions}

Thisstudy found that LTPA among adult women was not associated with the availability and accessibility of public parks in the neighborhoods where they live. Although our results do not support the view that neighborhood public parks have a direct effect on the proclivity of residents to engage in physical activity, these results highlight the need for a more systematic analysis of other built environment elements, as they seem to be intervening in the connection between neighborhood parks and LTPA among women in Hermosillo, M exico.

\section{Acknowledgments}

This article is based on research supported by grant D43TW 01276 from the National Institutes of Health/ Fogarty International Center and grant 1000-1241 from the Ford Foundation

\section{References}

Ainsworth, B. E., Sternfeld, B., Richardson, M. T., \& J ackson, K. (2000). Evaluation of the Kaiser Physical A ctivity Survey in women. M ed Sci SportsExerc, 32 (7), 1327-1338. doi:10.1097/ 00005768-200007000-00022

Baecke, J. A., Burema, J., \& Frijters, J. E. (1982). A short questionnairefor themeasurement of habitual physical activity in epidemiological studies. Am J Clin N utr, 36(5), 936-942. doi:10.1093/ ajch/36.5.936

Bermejo, J., Almagro, B., \& Rebollo, J. (2017). Factores motivacionales relacionados con laintención de seguir practicando ejercicio físico en mujeres adultasR etos, 34, 117-122. doi:https:/ / doi.org/ 10.47197/ retos. v0i34.50748

Blanco, 0.J., Soto, V. M., Benitez, H. Z., M ondaca, F. F., \& Jurado, G. P. (2019). Barreras parala práctica de ejercicio físico en universitariosmexicanoscomparaciones por género. Retos(36), 80-82. doi:https:/ / doi. org/ 10.47197/ retos. v36i36.67820

Bojorquez, I. , 0 jedarevah, L. \& Diaz, R. (2018).Accessto public spaces and physical activity for M exican adult women. Cad Saude Publica, 34(4), e00065217. doi:10.1590/ 0102$311 \times 00065217$

Carlson, J.A., Sallis, J. F., Conway, T. L., Saelens, B. E., Frank, L. D., Kerr, J., ... King, A. C. (2012). Interactions between psychosocial and builtenvironmentfactorsin explainingolder adults' physical activity. Prev M ed, 54(1), 68-73. doi:10.1016/ j.ypmed.2011.10.004

Casper, J. M., Harrolle, M. G., \& Kelley, K. (2013). Gender Differences in Self-Report Physical Activity and Park and Recreation Facility U seAmong LatinosinWakeCounty, North Carolina. Annals of Behavioral Medicine, 45(1), 49-54. doi:10.1007/ s12160-012-9435-9

Day, K. (2006).Activeliving and social justice: Planning for physical activity in low-income, Black, and Latino communities. Journal of theAmerican PlanningAssociation, 72(1), 88-99. doi:10.1080/ 01944360608976726

Diez-Roux,A.V., Link, B. G., \& Northridge, M. E. (2000).A multilevel analysis of incomeinequal ity and cardiovascular disease risk factors. Soc Sci Med, 50(5), 673-687. doi:https:/ / doi. org/ 10.1016/ 50277-9536(99)00320-2

Dugan, S. A. , Bromberger, J.T., Segava, E. , Avery, E., \& Sternfeld, B. (2015). Association between physical activity and depressive symptoms: midlife women in SWAN. M edicineand sciencein sports and exercise, 47(2), 335-342. doi:10.1249/ MSS.0000000000000407

Elshaha, S., O'Rorke, M., \&Adlakha, D. (2020). Builtenvironment correlates of physical activity in low- and middle-income countries:A systematic review. PLOSON E, 15(3), e0230454. doi:10.1371/ journal. pone.0230454

Evenson, K. R.,Williamson, S., Han, B., M cKenzie, T. L., \& Cohen, D.A. (2019). United States' neighborhood park useand physical activity over two years: TheN ational Study of N eighborhood Parks. Prev M ed, 123, 117-122. doi:https: / / doi.org/ 10.1016/ j.ypmed.2019.03.027

Filmer, D., \& Pritchett, L. (2001). EstimatingWeathEffectsW ithout Expenditure Data - O rTears:AnA pplicationTo Eductional Enrollments In States O f India. D emography(38), 115-132. doi:https: / / doi. org/ 10.1353/ dem.2001.0003

García-Pérez, H. , Harlow, S. D. , \& Denman, C. (2018). The effect 
of pelvic pain and urinary incontinenceon women's self-rated health in northern M exico. Int U rogynecol J, 29 (2), 243-250. doi:10.1007/ s00192-017-3537-7

GarcíaPérez, H., Harlow, S. D., Erdmann, C.A., \& Denman, C. (2010). Pelvic pain and associated character isticsamong women in nor thern M exico. Int Perspect Sex Reprod H ealth, 36 (2), 9098. doi:10.1363/ ipsrh.36.090.10

GarcíaPérez, H., \& Lara Valencia, F. (2016). Equidad en laprovisión deespaciospúblicosabiertos: accesibilidad, percepción y uso entremujeres de Hermosillo, Sonora. Sociedad y Ambiente(10), 28-56. doi:https:/ / doi.org/ 10.31840/ sya.v0i10.1651

Guimarães, L. M., Malta, D. C., M onteiro, C. N., daSilvaSousa, N. F., Stopa, S. R., M edina, L. d. P. B., \& deAzevedo Barros, M. B. (2019). Leisure-timephysical activity and sportsin theBrazilian population: A social disparity analysis. PLOS ONE, 14(12), e0225940. doi:10.1371/ journal. pone.0225940

Henderson, K. A., \& Gibson, H. J. (2013). An Integrative Review ofWomen, Gender, and Leisure: Increasing Complexities. Journal of Leisure Research, 45(2), 115-135. doi:10.18666/ jlr2013-v45-i2-3008

Hernandez, B., de Hæene, J., Barquera, S., M onterrubio, E., Rivera, J., Shamah, T., . . . Campirano, F. (2003). [Factorsassociated with physical activity among M exican women of childbearing age]. Rev Panam Salud Publica, 14(4), 235-245. doi:10.1590/ s1020-49892003000900004

IM PLAN. (2014). Programa de Desarrollo U rbano del Centro de Población deH ermosillo 2014. In Instituto M unicipal dePlaneación (Ed.), (pp. 260). Retrieved from http:/ / www.implanhermosillo.gob.mx

INEGI. (2005a). EncuestaN acional sobreU so delTiempo (ENUT) 2002. Instituto N acional deEstadística y Geografía, 80. Retrieved from https:/ / www. inegi.org mx/ contenido/ productos/ prod_serv/ contenidos/ espanol/ bvinegi/ productos/ historicos/76/ 702825498160/ 702825498160.pdf

INEGI. (2005b). [Second Population Count 2005. BasicTabulation]. In. Aguascalientes, Mexico: Instituto Nacional deEstadisticae Informatica

INEGI. (2016). Encuesta Nacional deVictimización y Percepción sobre Seguridad Pública (EN VIPE) 2016. . Retrieved from Aguascalientes, Mexico:

INEGI. (2019). EncuestaN acional deV ictimización y Percepción sobre Seguridad Pública(EN VIPE) 2019. . Bol ein deprensa, 32. Retrieved from https:/ / www. inegi.org mx/ contenidos/ programas/ envipe/ 2019/ doc/ envipe2019_son.pdf

INEGI. (2020). Resultados del módulo de prácticadeportivay ejercicio físico (M O PRADEF) 2019 [Press release]. Retrieved from https:/ / www.inegi.org.mx/ contenidos/ saladeprensa/ boletines/ 2020/ EstSociodemo/ mopradef2020. pdf

IN SP, SS, \& INEGI. (2018). EncuestaN acional de Salud y N utrición 2018., pp.42. Retrieved from https:// www.inegi.org mx/ contenidos/ programas/ ensanut/ 2018/ doc/ ensanut 2018 presentacion resultados.pdf

Jáuregui, A., Pratt, M., Lamadrid-Figueroa, H., Hernández, B., Rivera, J. A., \& Salvo, D. (2016). Perceived N eighborhood Environment and Physical Activity:TheInternational Physical
Activity and Environment N etworkA dult Study in M exico. Am J Prev Med, 51(2), 271-279. doi:10.1016/ j.amepre.2016.03.026

Jáuregui, A., Salvo, D., Lamadrid-Figueroa, H., Hernández, B., Rivera, J., \& Pratt, M. (2017). Perceived neighborhood environmental attributes associated with leisure-time and transport physical activity in M exican adults. Prev M ed, 103, S21-S26. doi:https:/ / doi. org/ 10.1016/ j.ypmed.2016.11.014 Jáuregui, A., Sal vo, D., Medina, C., Barquera, S. \& Hammond, D. (2020). Understanding the contribution of public- and restricted-accessplacesto overall and domain-specific physical activity among M exican adults: A cross-sectional study. PLOS ONE, 15(2), e0228491. doi:10.1371/ journal. pone.0228491

Johnson-Lawrence, V., Schulz, A. J., Zenk, S. N., Isræel, B. A., \& Rowe, Z. (2015). Doesterritoriality modify therelationship between perceived neighborhood challenges and physical activity?A multilevel analysis. Ann Epidemiol, 25 (2), 107-112. doi:10.1016/ j.annepidem. 2014.11.019

Joseph, R. P., \& Maddock, J. E. (2016). 0 bservational Park-based physical activity studies: A systematic review of the literature. Prev M ed, 89 (Supplement C), 257-277. doi:doi: 10.1016/ j.ypmed. 2016.06.016

Kaczynski, A.T., Besenyi, G. M. ., Stanis, S. A.W., Koohsari, M. .., O estman, K. B. , Bergstrom, R. , . . Reis, R. S. (2014). Are park proximity and park featuresrelated to park use and parkbased physical activity among adults?Variations by multiple socio-demographic characteristics. International Journal of Behavioral Nutrition and Physical Activity, 11(1), 1-14. do:10.1186/ s12966-014-0146-4

Lambiase, M. J., \&Thurston, R. C. (2013). Physical activity and sleep among midlife women with vasomotor symptoms. Menopause, 20(9), 946-952. doi:10.1097/ GME.0b013e3182844110

Lara-Valencia, F., \& García-Pérez, H. (2015). Spacefor equity: socioeconomic variations in the provision of public parks in Hermosillo, Mexico. Local Environment, 20(3), 350-368. doi:10.1080/ 13549839.2013.857647

Lara-Valencia, F., \& GarcíaPérez, H. (2020). ThreeEcologies of the U rban Environment and the Health of Latinx Communities. InA. D. Martinez\& S. D. Rhodes (Eds.), N ew and Emerging Issuesin Latinx H ealth (pp. 271-294). N ewYork: Springer.

Mitáśs, J., Cerin, E., Reis, R. S., Conway, T. L., Cain, K. L.,Adams, M. A.,... Sallis, J. F. (2019). Do associations of sex, age and education with transportand leisuretimephysical activity differ across 17 citiesin 12 countries? International Journal of Behavioral Nutrition and Physical Activity, 16(1), 121. doi:10.1186/ s12966019-0894-2

Monforte, J., \& Colomer, J.Ú. (2019). 'Como unachica': unestudio provocativo sobre estereotipos de género en educación física('Likeagirl': aprovocativestudy on gender stereotypes in physical education). Retos: nuevastendencias en educación física, deporte y recreación(36), 74-79. doi:https:/ / doi.org/ 10.47197/ retos. v36i36.68598

Nagel, C. L., Carlson, N. E., Bosworth, M., \& Michael,Y. L. (2008). 
The Relation between Neighborhood Built Environment and Walking Activity among O Ider Adults. American Journal of Epidemiology, 168(4), 461-468. doi:10.1093/ aje/ kwn158

Nakamura, P. M., Teixeira, I. P., Hino,A.A. F., Kerr,J., \& Kokubun, E. (2016).Association between privteand public placesand practice of physical activityinadults. Revisa Brasilerra deCineantropomerria \& DesempenhoH umano,18, 297-310. doi:http:/ / dx.doi.org/ 10.5007/ 1980-0037.2016v18n3p297

O jedaRevah, L., Bojorquez, I., \& O suna, J. C. (2017). How thelegal frameworkfor urban parksdesign affectsuser satisfaction inaL atin American city. Cities, 69, 12-19. doi:https:/ / doi.org/ 10.1016/ j.áties.2017.05.016

Pafi, M., Siragusa, A., Ferri, S., \& Halkia, M. (2016). Measuring the A ccessibility of $U$ rban Green Areas.A comparison of the Green ESM with other datasts in four European cities (EUR 28068 EN). Retrieved from Luxembourg: http:/ / publications.jrc. ec.europa.eu/ repository/bitstream/ JRC102525/ 190916 siragusa_\%20irc_techrep_accessibility_online.pdf

Parra, D.C., Gómez, L. F., Fleischer, N. L., \& Pinzón,J. D. (2010). Built environment characteristicsand perceived active park useamong older adults, resultsfromamultilevel studyin Bogota Health Place, 16(6), 1174-1181. doi:10.1016/ j.hedthplace.2010.07.008

Raudenbush, S. W., \& Bryk, A. S. (2002). H ierarchical Linear M odels: Applicationsand Data AnalysisM Methods (2nd ed.). N ewbury Park, CA: Sage.

RodríguezGuajardo, R., Salazar Cantú, J., \& CruzRamos,A. (2013). Determinantes delaactividad físicaen M éxico. Estudios Sociales: Revisa deinvestigación científica, 21(41), 185-209.

RojasdeP, E., Molina, R., \& Rodríguez, C. (2012). D efinición, clasifica cióny diagnóstico deladiabetesmellitus Revistavenezolana deEndocrinología y M etabolismo,10, 7-12. doi:1690-3110

Ross, A., \& Searle, M . (2019). A Conceptual M odel of LeisureT ime Physical Activity, Neighborhood Environment, and Sense of Community. Environmentand Behavior,51(6), 749-781. doi:10.1177/ 0013916517751582

Salvo, D., Reis, R. S., Sarmiento, O. L., \&Prat, M. (2014). O vercoming thechallenges of conducting physical activity and builtenvironment researchin LatinAmerica: IPEN LatinAmerica Prev M ed, 69, S86S92. doi:https/ / doi.org/ 10.1016/ j.ypmed.2014.10.014

Salvo, D., Sarmiento, O. L., Reis, R. S., Hino, A. F., Bolivar, M. A., Lemoine, P. D., . . Pratt, M. (2017).W here LatinA mericansare physically active, and why doesitmatter? Findingsfrom theIPEN adultstudyinBogota, Colombia; Cuernavaca, Mexico; andCuritiba, Brazil. Pre/M ed, 103s, 527-s33. doi:10.1016/ j.ypmed.2016.09.007

Schipperijn, J., Bentsen, P., Troelsen, J.,Toftager, M., \& Stigsdotter, U. K. (2013). Associationsbetween physical activity and characteristics of urban green space. U rban Foretry \& U rban Greening, 12 (1), 109116. doi:https/ / doi.org/10.1016/ j.ufug2012.12.002

Schipperijn,J., Cerin, E., Adams, M. A., Reis, R., Smith, G., Cain, K., . .. Sall is, J. F. (2017).Accessto parksand physical activity: An eight country comparison. U rban Forestry \& U rban Greening, 27, 253-263. doi:https:/ / doi.org/ 10.1016/ j.urug2017.08.010

Schulz,A., Menz, G., Johnson-LawrenceV., Isral, B.A., Max, P.,Zenk, S. N., . . Marans, R.W. (2013). Independentand joint associations between multiplemeasuresof thebuiltand social environmentand physica activityin amulti-ethnic urban community. Journal of U rban Health, 90(5), 872-887. doi:10.1007/ sl1524-013-9793-z
SEDESO L. (1999). Sistema N ormativo deEquipamiento U rbano. In SecretaríadeDesarrollo Social (Ed.), (Vol.TomoV: Recreación y Deporte).

SEDESO L. (2010). Documento Diagnósico deRescatedeEspaciosPúblicos. In SecretaríadeD esarrollo Social (Ed.). Retrieved from http:/ / www. sedesol.gob. mx/ work/ models/ SEDESO L/ Sedesol/ sppe/ dgap/diagnostico/ Diagnostico_PREP.pdf

Shamah-Lew,T., Romero-Martínezz, M., Cuevas-Nasu, L., Méndez Gómez-Humaran, I., Antonio AvilaArcos, M., \& Rivera Dommacc, J.A. (2019).TheM exicanNational Heathand Nutrition Survey asaBasisfor PublicPolicy Planning: 0 verweightand 0 besity. Nutrients, 11(8), 1727. doi:10.3390/ nul1081727

Soltero, E., Scherezade, K. M., Pacheco,A., \& Lee, R. (2015). Physical ActivityResourceandUser CharacteristicsinPuertoVallarta, Mexico. Retos, 28, 203-206. doi:https:/ / doi.org/ 10.47197/ retos. voiz2.34956

Stewart, O.T., M oudon,A.V., Littman,A. J., Seto, E. \& \& Saelens, B. E. (2018).W hyneighborhood park proximityisnotassocided with total physical activity. H ealth Place,52, 163-169. doi:https/ / doi. org/ 10.1016/ j.healthplace.2018.05.011

Stodolska, M. (2000). LookingBeyond thelnvisible: Can Researchon LesureofEthnicand Racial M inoritiesContributeto LeisureTheory? Journal of LeisureRecearch, 32, 156. doi:https:/ / doi.org/10.1080/ 00222216.2000 .11949907

Sugiyama, T., Giles-Corti, B., Summers, ., duToit, L., Leslie, E., \& O wen, N. (2013). Initiating and maintaining recreational waking:A longitudinal study on theinfluence of neighborhood green space. Prev M ed, 57(3), 178-182. doi:https:/ / doi.org/ 10.1016/ j.ypmed.2013.05.015

Sundquist, K ., \&Yang, M. (2007). Linking social capital and self-rated health: amultilevel analysisof 11,175 men and women in Sw eden. Health Place, 13(2), 324-334. do:10.1016/ j.healthplace.2006.02.002

Talavera, L. M. , \& Saldaña, L. M. (2020). Diferenciasdegénero en el perfil yloshábitosdepracticantesdeactividadesen el medio natural. Retos nuevastendenciasen educación físca, deportey recreación(38), 713-718. doi:https/ / doi.org/ 10.47197/ retos.v38i38. 78499

Talen, E. (1997). The social equity of urban service distribution an exploration of parkaccessin Pueblo, Colorado, andM acon, Georga U rban Geography,18(6), 521-541. doi:https:/ / doi.org/ 10.2747/ 0272-3638.18.6.521

Valenzuela, G. M. E., \& M eléndez, J. M. (2019). Normalización del cuerpo femenino. M odelosy prácticascorporalesdemujeresjóvenes del noroeste de M éxico. Región y Sociedad, 31. doi:https: / / doi.org/ 10.22198/ rys2019/ 31/ 1067

W HO. (2020). WH O guidelineson physical activity and sedentary behaviour. Retrieved from Geneva: https: / / apps who. int/ iris/ bitstream/ handle/ 10665/336656/9789240015128engpdf?sequence $=1$ \&isAllowed $=\mathrm{y}$

W rightWendel, H.E.,Zarger,R.K., \& Miheldic,J.R. (2012).Accessibility and usability: Green spacepreferences, perceptions, and barriersin a rapidly urbanizing city in Latin America. Landscape and $U$ rban Planning, 107(3), 272-282. doi:https:/ / doi.org/ 10.1016/ j.landurbplan.2012.06.003

Ziviani,J.,Wadley, D.,Ward, H., Macdonald, D., Jenkins, D., \& Rodger, S. (2008).A placeto play: socioeconomic and spatiaf factorsinchildren's physical activity. Australian Occupational Therapy Journal, 55(1), 211. doi:https/ / doi.org/ 10.1111/ j.1440-1630.2006.00646.x 